\title{
Spinal tumors in children
}

Andrei Fernandes Joaquim ${ }^{1,2 *}$, Enrico Ghizoni ${ }^{1,2}$, Marcelo Gomes Cordeiro Valadares ${ }^{1,2}$, Simone Appenzeller ${ }^{3}$, Simone dos

Santos Aguiar ${ }^{2}$, Helder Tedesch1 ${ }^{1,2}$

${ }^{1}$ Discipline of Neurosurgery, Department of Neurology, Universidade Estadual de Campinas (Unicamp), Campinas, SP, Brazil

${ }^{2}$ Department of Pediatric Oncology, Centro Infantil Boldrini, Campinas, SP, Brazil

${ }^{3}$ Department of Medicine, Unicamp, Campinas, SP, Brazil

Study conducted by Discipline of Neurosurgery, Department of Neurology, Universidade Estadual de Campinas

(Unicamp), Campinas, SP, Brazil

Article received: $10 / 19 / 2016$ Accepted for publication: 11/20/2016

*Correspondence: Divisão de Neurocirurgia Departamento de Neurologia Unicamp

Address: Rua Tessália Vieira de Camargo, 126, Cidade Universitária Zeferino Vaz Campinas, SP - Brazil Postal code: $13083-887$ andjoaquim@yahoo.com

http://dx.doi.org/10.1590/1806-9282.63.05.459

\section{SUMMARY}

Introduction: Spinal tumors are rare in the pediatric population, presenting many specific peculiarities when compared to adults. We have performed a broad narrative review to describe the most common spinal tumors in children, discussing their main characteristics and management options.

Method: The authors have performed an extensive review of the peer-reviewed literature addressing the aforementioned objectives.

Results: Multimodality radiological studies (plain films, 3D computed tomography scan and magnetic resonance imaging) are necessary for proper evaluation and differential diagnosis of spinal tumors in children. In selected cases nuclear medicine imaging is used to improve the chances of a more accurate diagnosis. As a general rule, a fine needle biopsy is recommended after radiological evaluation to confirm the tumor's histology. Primary bone tumors can be divided into benign bone tumors, mostly represented by vertebral hemangiomas, osteoid osteomas, osteoblastomas, aneurismal bone cysts, and eosinophilic granulomas, and malign or aggressive tumors, such as Ewing's or osteogenic sarcomas. Secondary bone tumors (spinal metastases) comprise different tumor histologies, and treatment is mainly based on tumor's radiosensitivity. The characteristics and treatment options of the main spinal tumors are discussed in details.

Conclusion: Spinal tumors in children are rare lesions that demand a thorough understanding of their main characteristics for their proper management. Understanding the nuances of spinal tumors in children is of paramount importance for improving outcomes and chances of cure.

Keywords: spinal tumors, children, adolescent, management, treatment, spine.

\section{INTRODUCTION}

Spinal tumors are rare in pediatric populations. In children, spinal diseases also have many specific peculiarities compared to adults. For instance, persistent pain lasting more than two months in children is often associated with a specific diagnosable lesion in up to $85 \%$ of patients. ${ }^{1}$ As for spinal tumors, clinical symptoms may include not only pain, but fever, weight loss, weakness, neurological deficits, bowel and bladder dysfunction, and more. ${ }^{2-4}$ Since spinal tumors are rare in children, a high level of suspicion is necessary for early diagnosis and treatment. Recognizing red flags (such as weight loss, neurological deficits, systemic symptoms, previous history of malignancy or serious illness, persistent and progressive pain, etc.) is mandatory for adequate and timely radiological diagnosis. ${ }^{2-4}$ The sensitivity of radiological imaging in diagnosing tumors in children depends on tumor size and histology. Radiological imaging is based on simple plain radiographies, three-dimensional (3D) reconstruction computer tomography (CT) scan and magnetic resonance imaging (MRI). Most of the time, multimodality evaluation, which includes nuclear medicine image, is necessary to improve the chances of accurate diagnosis and proper medical management. After radiological evaluation, a fine needle biopsy is recommended to confirm tumor histology and guide treatment, as well as laboratorial evaluation for screening systemic disease. ${ }^{5}$ A flowchart including clinical history, radiological evaluation and histological 
diagnosis is proposed to facilitate the initial investigation of children with potential spinal tumors (Figure 1).

Considering the nuances involved in the diagnosis and management of spinal tumors affecting the pediatric population, we have performed a broad narrative review of this topic in order to help pediatricians and surgeons in the initial evaluation of these patients.

\section{Method}

We conducted an extensive review of the peer-reviewed literature addressing articles related to spinal tumors in children including articles found in the Pubmed Database without time restriction. A combination of the following search terms has been used either combined or grouped: "spine tumors;" "metastases;" "pediatric." For didactic reasons, we have divided the main spinal tumors into two large groups: 1) Primary bone tumors and 2) Metastatic bone tumors. We have included articles that focused on the epidemiology, clinical and radiological presentation, differential diagnosis using radiological evaluation, and potential treatment modalities of the most common spinal tumors in children.

\section{Results}

Although children may also have metastases, most bone tumors in the pediatric population are solitary and primary vertebral tumors. ${ }^{6}$ The following are the clinical and radiological features of the most common spinal bone tumors in children.

\section{Primary bone tumors}

\section{Benign bone tumors}

These tumors would not spread to other areas, but may grow and compress adjacent structures and present with severe clinical symptoms and functional impairment. ${ }^{7}$

\section{Vertebral hemangiomas}

These are the most common tumors discovered incidentally on radiological exams and also the most common benign vertebral neoplasms (incidence of almost $10 \%$ in autopsy). ${ }^{8}$ The vast majority is focal and asymptomatic. ${ }^{9}$ Histologically, they show thin walls, blood-filled vessels and sinuses lined by endothelium with trabeculated bone interspersed. ${ }^{9}$ Radiologically, they are represented by vascular channels with multifocal lytic areas with honeycomb appearance. CT scan (axial cut) shows a speckled pattern secondary to the vertical trabeculae in cross section views (polka dot sign). ${ }^{10}$ Asymptomatic lesions on the MRI present with hyper signal in T1 and T2 sequences (due to its fatty component), with significant gadolinium enhancement due to their high vascularity. Some hemangiomas may have an aggressive behavior, resulting in symptomatic spinal cord compression due to extraosseous extension of the tumor, vertebral fracture or even enlargement of adjacent

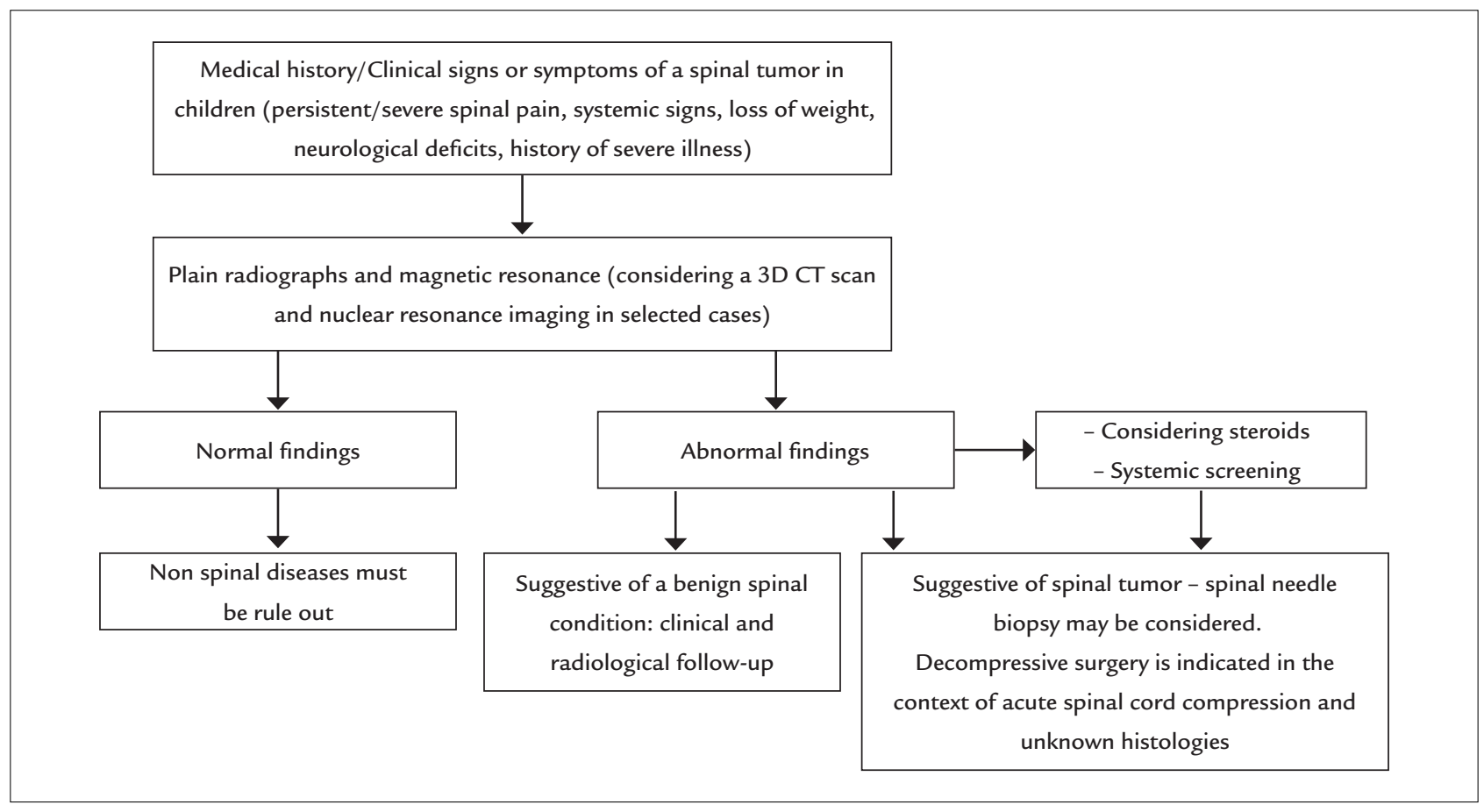

FIGURE 1 Flowchart for helping the initial management of children with a suspected spinal tumor. 
blood vessels. Extraosseous involvement is associated with an inverse relation of fatty component inside the hemangioma: low signal intensity on T1-weighted images may suggest greater aggressiveness. Of note, metastases are the main differential diagnosis and generally also have a decreased T1 signal intensity. The thoracic region is the site of up to $90 \%$ of all aggressive hemangiomas, generally from T3 to T9. ${ }^{10}$ Since they are mostly benign and usually asymptomatic, treatment is rarely necessary, and reserved for expansible and symptomatic lesions only. Treatment modalities may include vertebroplasty, balloon kyphoplasty, transarterial embolization, radiotherapy or even surgical decompression with stabilization. ${ }^{10-13}$ Formal en bloc resection is not required for this tumor in most cases, since excellent rates of local control and long-term survival can be obtained with intralesional resection alone..$^{11,14}$

\section{Osteoid osteoma}

It accounts for $11 \%$ of all benign bone tumors, with a higher incidence in males from 5 to 24 years of age. ${ }^{15-18}$ Spinal osteomas are generally about 1 to $2 \mathrm{~cm}$ in size, with a radiolucent nidus and clear margins from the reactive periosteal bone. ${ }^{19}$ It classically manifests as a well-localized night pain that may be relieved with salicylates. A compensatory scoliosis secondary to muscle spasms can be found in the concave side of the tumor. ${ }^{20}$ Most of the lesions are found in the posterior spinal elements (lamina, transverse processes, pedicles), mainly in the lumbar spine, followed by the cervical, thoracic and sacral region, respectively. Radiologically, plain films may be normal or show a solid periosteal reaction with cortical thickening and a well-circumscribed central lucent area. ${ }^{21-25} \mathrm{CT}$ scan is the modality of choice for diagnosis, as it displays a focal calcified nidus within surrounding sclerotic reactive bone. Scintigraphy with technetium-99m shows typical focal uptake and a double density sign that is highly specific. $^{15,17,18}$ Finally, MRI can be sensitive, but may not identify the nidus as precisely as CT scans. Since spontaneous regression has been reported, treatment is performed only when the patient is symptomatic. When symptoms are mild or moderate long-term administration of anti-inflammatory drugs can be used as a treatment option. Surgical resection, curettage or even radiofrequency ablation are other treatment options available for different particular cases according to tumor location, intensity of symptoms, and the surgeon's experience and preference. ${ }^{20}$

\section{Osteoblastoma}

It is represented by tumors that are histologically identical to osteoid osteomas. This type differs from osteoid oste- oma in that it can grow larger than $1 \mathrm{~cm}$ in diameter and has a more aggressive behavior. ${ }^{21,22}$ It is much rarer than osteoid osteoma, but affects patients in the same age group, also with a predilection towards the male sex. ${ }^{22}$ Similar to osteomas, they can affect all sites of the vertebral column, especially the posterior elements. ${ }^{6,23} \mathrm{~A}$ histological variant with an aggressive behavior has been reported, with a high number of epithelioid osteoblasts and nuclear atypia some authors reported this variation as a low grade osteosarcoma even without proper sarcomatous tissue., ${ }^{4,13}$ Most of these tumors may be first noted as a palpable mass, and some of them may result in cord compression due to their large size. ${ }^{3,4}$ Radiologically, plain films may show a lytic lesion with a rim of reactive sclerosis, with or without internal calcification and some surrounding sclerosis or periostitis. CT scan is better than MRI for diagnosis, showing a lytic lesion with varying degrees of matrix mineralization. On MRI, image findings can be non-specific. It usually shows a lesion with hypo- or isointense $\mathrm{T} 1$ and $\mathrm{T} 2$ central areas (calcification foci) and a hyperintense T2 sign in surrounding bone and soft tissues. It usually enhances with gadolinium. ${ }^{21}$ Scintigraphy with technetium-99m shows typical focal uptake suggesting increased bone turnover. The treatment of choice consists of complete surgical excision, if possible, preferentially with pre-operative embolization to minimize bleeding., ${ }^{3,13,22}$

\section{Aneurysmal bone cyst ( $A B C)$}

This is a benign expansible bone tumor (the neoplastic etiology is controversial), consisting of blood-filled spaces separated by connective tissue containing trabeculae of bone or osteoid or osteoclast tissues. ${ }^{24,25}$ Most ABCs are primary, but up to one third may be associated with others tumors, such as osteosarcomas, chondroblastomas, fibrous dysplasia, and giant cell tumors. ${ }^{25,26}$ They can affect all segments in the spine, preferentially involving posterior elements and the vertebral body. ${ }^{4,25,26}$ Radiologically, plain films may show a sharply defined expansible osteolytic lesion, with thin sclerotic margins. CT scan evaluation is similar to plain films, but may also demonstrate a collection of clear fluid, seen more clearly on MRI. ${ }^{25}$ If a solid component is visualized on MRI, a secondary ABC may be suspected. ${ }^{4}$ Most of the cysts have a low T1 and T2 signal, but high-signal focal areas are commonly seen due to the variable degrees of blood decomposition inside the cysts. ${ }^{4}$ The septations may enhance with gadolinium administration. Treatment depends on the location and extension of the $\mathrm{ABC}$, but it is based on surgical resection. Pre-operative embolization is advised to reduce intraoperative blood loss. A higher recurrence rate is reported 
with partial resection or curettage and bone grafting. Total surgical resection is the best treatment to reduce the rate of recurrence, but it increases morbidity. ${ }^{27}$ Serial embolization as an isolated treatment can be indicated for patients with recurrent lesions after previous surgical treatment or in whom surgery would not be tolerated due to comorbidities or complexity. ${ }^{28}$ An illustrative case of thoracic spine $A B C$ is presented in Figure 2.

\section{Eosinophilic granuloma (EG)}

$\mathrm{EG}$ is the term used for describing single lesions composed of Langerhans cell histiocytosis. ${ }^{29,30}$ It encompasses many different conditions characterized by the presence of granulomatous lesions with Langerhans cells..$^{29,30}$ The peak of incidence is from 1 to 3 years, affecting more males than females. ${ }^{4}$ The spine is the second most common site affected, just after the skull, in the cervical, thoracic and lumbar vertebrae, respectively. It may cause vertebral collapse, radiologically represented as vertebra plana, which is the most common development of EG in children (in this age group the differential diagnosis of vertebra plana is non-Hodgkin lymphoma). ${ }^{31,32}$ Clinically, EGs may cause back pain and neurological deficits. Plain films and CT scans may show a lytic lesion without sclerotic rim or

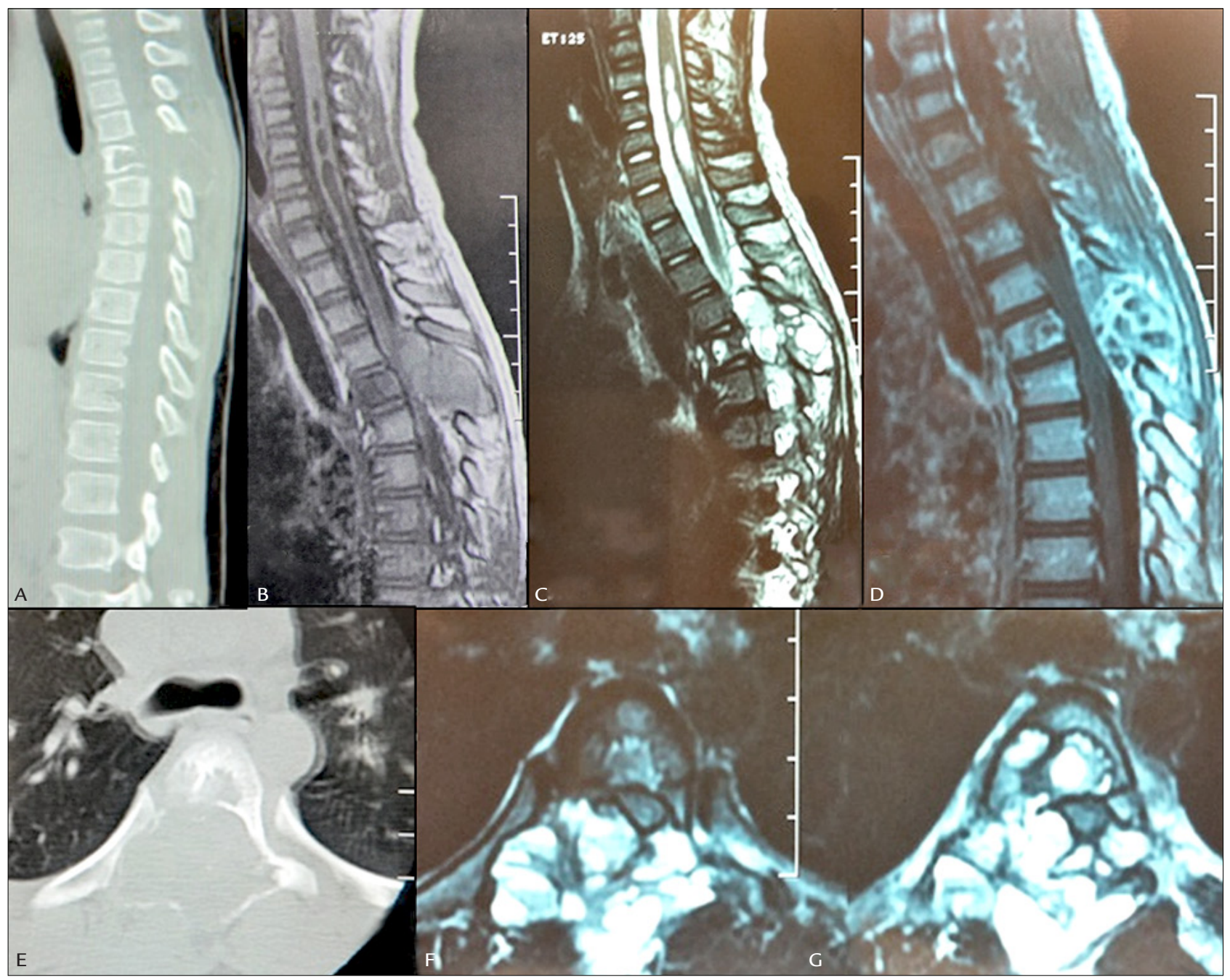

FIGURE 2 This 5 year-old patient was brought to the emergence department with 2-week progressive leg weakness and thoracic pain. A. Sagittal CT scan with a T5 osteolytic lesion involving the spinous process, pedicles and the posterior vertebral body. B. A Sagittal T1 sequence MRI showing iso signal lesion at the posterior elements of T5 and spinal cord compression. C. Sagittal T2 sequence MRI with a hypersignal heterogeneous lesions and spinal cord compression. D. Sagittal T1 sequence with gadolinium showing irregular enhancement. E. Axial CT scan showing a lytic lesion with insufflation, the same showing in axial T2 sequence, with a heterogeneous insufflation T2 hyper signal lesion with fluid content. The anatomopathological exam confirms an aneurismatic bone cyst. 
vertebra plana. MRI generally presents with T1 hypointensity sign lesion, T2 hypointensity signal lesion, and gadolinium enhancement. ${ }^{29}$ The prognosis is good in confined disease. ${ }^{4,30,31}$ Treatment may be non-surgical in cases where symptoms are mild and there are no neurological deficits, since fibrosis occurs spontaneously in 1 to 2 years, but chemotherapy should be considered in systemic forms of the disease. ${ }^{4,30,31}$ Surgical treatment may consist of biopsy for diagnosis, followed by curettage, steroid therapy, radiotherapy and/or decompression with or without fixation in cases of spinal cord compression. ${ }^{4,30,31}$

\section{Malignant/Aggressive bone tumors \\ Ewing's sarcoma (ES)}

About $65 \%$ of the cases of ES occur in the second decade of life, predominantly in males. ${ }^{33}$ Only a small portion of them occurs in the spine; however, it is the most common non-lymphoproliferative primary malignant tumor of the spine in children. ${ }^{33,34}$ Primary vertebral ES has been divided into sacral and non-sacral, based on treatment responses and survival rates (non-sacral types are rarer and have a better treatment response and survival rate). ${ }^{35}$ Skeletal scintigraphy for staging is mandatory, since ES is generally a multifocal disease. Clinically, patients may present with persistent pain and swelling, due to its expansible nature, as well as secondary neurological deficits. Plain films may show lytic changes or vertebra plana. ${ }^{35}$ CT scan is useful for determining the extent of involvement of both the vertebral body and the posterior elements. MRI is sensitive to detect ES in the spine, as well as to evaluate epidural compression and soft tissue involvement. ${ }^{35,36}$ Generally, ES has a low-to-isointense signal compared with muscle on T1-weighted images and high signal on T2-weighted images, with heterogeneous enhancement with gadolinium. These findings are nonspecific. MRI is also important for monitoring the response to chemotherapy and preoperative planning.

Treatment depends on the degree of the disease: focal tumors without neurological deficits confirmed by needle biopsy may receive neoadjuvant chemotherapy to shrink the tumor and treat micrometastases, followed by surgery with wide resection and/or radiotherapy, and adjuvant chemotherapy. ${ }^{35,36}$

\section{Osteogenic sarcoma}

Primary spinal osteosarcoma is a rare lesion. Differential diagnosis is mainly osteoblastoma, which preferentially involves the posterior elements and extends into the vertebral body, while osteosarcomas generally occur in the vertebral body and extend to the posterior elements. ${ }^{4,37}$
The most common location is in the lumbar spine and sacrum. Pain occurs in the vast majority of patients, with neurological deficits in about $70 \%$ of them. ${ }^{4,37}$

Histologically, it is characterized by cells of varying shapes, with hyperchromatic nuclei, producing osteoid or bone. It is a malignant tumor of the connective tissue. ${ }^{37}$

Radiologically, plain films may show a blastic lesion or osteolysis. Sometimes a purely lytic pattern may be visualized as well. CT scan may show the mineralization pattern of lytic lesions and is the modality of choice for evaluating cortical destruction. ${ }^{38} \mathrm{MRI}$ is nonspecific due to tumor heterogeneity: on T1-weighted images, ossified components may have low signal, soft tissue may have intermediate signal, and hemorrhage will have variable signal intensity; on T2, soft tissue and peri-tumoral edema will have high signal intensity, whereas ossified components will present with low signal. Solid components of the tumor enhance with gadolinium..$^{38}$ Ossified components/dense mineralization show as low signal changes in all sequences. Clear fluid may be present, as a differential diagnosis with $\mathrm{ABC} .{ }^{38}$

The current treatment of choice is en bloc resection, especially for tumors confined to the vertebral body, followed by adjuvant radiotherapy and chemotherapy. The survival rates of primary spinal osteosarcomas are lower than non-spinal tumors (overall survival rates of about 30 to $40 \%$ in 5 years). ${ }^{37,38}$

\section{Secondary bone tumors/Spinal metastases}

Spinal metastases are the most common tumors in the spine of adults, comprising 70 to $80 \%$ of all spinal tumors in this age group. ${ }^{39}$ Although spinal metastases are much rarer in children, with the advances in chemotherapy, surgical techniques and also the new modalities of radiation, children with malignant tumors are living more and also presenting with spinal metastases. ${ }^{40}$ Of note, although spinal cord compression can occur in the setting of leukemia and lymphoma, they are not truly spinal metastases, since they are not solid tumors. The modality of choice for diagnosing spinal metastasis in children is MRI, which can assess the vertebrae and the spinal cord, as well as evaluate multiple sites of compression..$^{40,41}$

In a large series of 2,259 solid malignant tumors in children, 5\% (112 patients) developed spinal epidural metastases with cord compression during treatment. ${ }^{40}$ The most common cause was ES and neuroblastoma, followed by osteogenic sarcoma, rhabdomyosarcoma, Hodgkin's disease, soft tissue sarcoma, germ-cell tumor, Wilm's tumor and hepatoma ${ }^{40}$ Outcome was similar for small-cell tumors (neuroblastomas, Hodgkin's disease and germ-cell tumors) 
that received chemotherapy and/or radiation therapy or a decompressive laminectomy alone prior to chemotherapy and/or radiation therapy. On the other hand, children with metastatic sarcomas (soft-tissue sarcoma, osteogenic sarcoma, rhabdomyosarcoma) had a better neurological outcome with decompressive laminectomy followed by radio and/or chemotherapy than those without surgery.

A flowchart is suggested for helping the management of spinal metastases in children (Figure 3). The main consideration for treatment is tumor histology and its response to radiotherapy and/or chemotherapy. As a rule, radiation therapy is used as first treatment modality in radiosensitive tumors, and surgery is proposed to relieve spinal cord compression, especially in radioresistant tumors, such as sarcomas, or when deformity (kyphosis and/or scoliosis) or spinal instability are present.

In children, special concerns with spinal deformities must be taken into account when operating on a spinal tumor or even after radiotherapy ${ }^{42}$ Clinical and radiological follow-up of post-treatment deformities is mandatory, and bracing may be considered in selected cases, especially after decompressive procedures without spinal stabilization in young children. ${ }^{42}$

\section{Conclusion}

Spinal tumors in children are rare lesions. After clinical suspicion, initial evaluation may include 3D CT scans and
MRI. Needle biopsy is recommended in most cases for diagnosis confirmation. Primary bone tumors may be benign, where treatment is individualized, or malignant, potentially requiring en bloc resection. Spinal metastases in children, although rare, can be treated without surgery in tumors that are responsive to chemotherapy and/or radiation therapy; surgery is reserved for specific situations (such as acute and progressive spinal cord compression or patients with instability) or tumors not responsive to adjuvant treatment. Understanding nuances of spinal tumors in children is paramount for improving outcomes and chances of cure.

\section{AcKnowledgment}

We thank Dr. Willian G. J. Teixeira for the enriching comments.

\section{Resumo}

Tumores de coluna em crianças

Introdução: Os tumores de coluna em crianças são raros, apresentando peculiaridades únicas quando comparados com os da população adulta.

Método: Dada a escassez de trabalhos que avaliem o tema, realizou-se extensa revisão de literatura objetivando descrever os tumores de coluna que acometem a população pediátrica, discutindo características e opções de manejo.

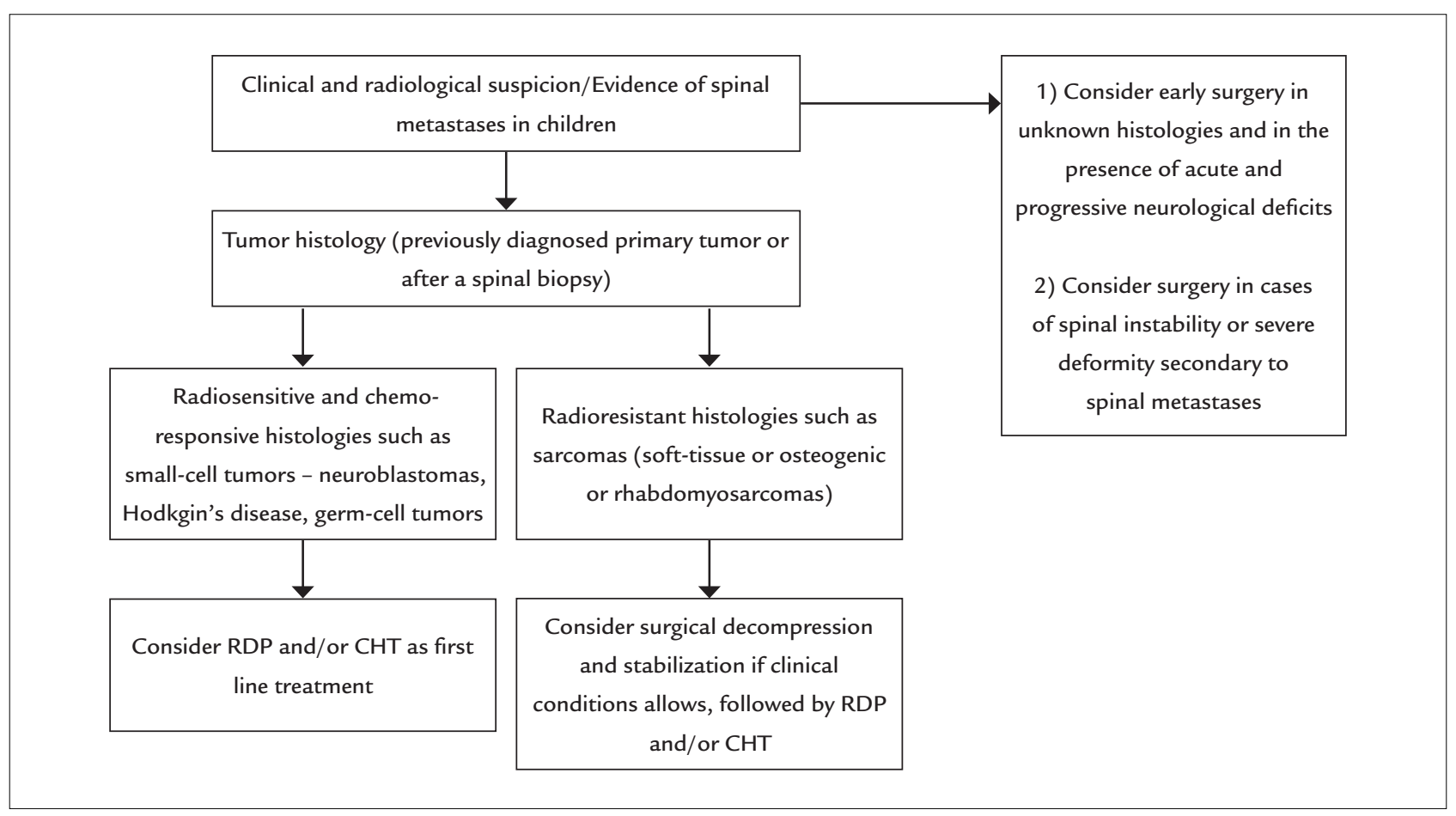

FIGURE 3 Flowchart to facilitate initial management of spinal metastases in children. 
Resultados: A utilização de exames radiológicos combinados (radiografias, tomografia computadorizada com reconstrução em 3D e ressonância magnética) é necessária para avaliação adequada e diagnóstico diferencial dessas lesões. Em casos selecionados, exames de medicina nuclear aumentam as chances do diagnóstico preciso. Como regra geral, biópsia por agulha é recomendada para confirmação da histologia tumoral e tratamento subsequente. As lesões primárias de coluna podem ser benignas, representadas principalmente pelos hemangiomas, osteomas osteoides, osteoblastomas, cistos ósseos aneurismáticos e granulomas eosinofílicos, enquanto as lesões malignas são geralmente representadas por tumores agressivos, como o sarcoma de Ewing ou os sarcomas osteogênicos. Metástases de coluna podem ter diferentes etiologias, sendo o tratamento dependente principalmente da radiossensibilidade do tumor de origem. As opções de tratamento dessas lesões são descritas em detalhes.

Conclusão: Tumores de coluna em crianças são raros e o seu manejo requer um conhecimento amplo e variado das diferentes possibilidades diagnósticas. Conhecer os nuances envolvidos no tratamento dessas lesões e os sintomas iniciais é fundamental para melhorar o prognóstico e as chances de cura.

Palavras-chave: tumores da coluna, criança, adolescente, manejo, tratamento, coluna.

\section{References}

1. Berrman R, Kliegman RM, Arvin AM. Nelson's textbook of pediatrics. 15. ed. Philadelphia: W.B. Saunders Company; 1996.

2. Beer SJ, Menezes AH. Primary tumors of the spine in children: natural history, management, and long-term follow-up. Spine (Phila Pa). 1997; 22(6):649-58.

3. Fenoy AJ, Greenlee JD, Menezes AH, Donovan KA, Sato Y, Hitchon PW, et al. Primary bone tumors of the spine in children. J Neurosurg. 2006; 105(4):252-60.

4. Graham GN, Browne H. Primary bony tumors of the pediatric spine. Yale J Biol Med. 2001; 74(1):1-8.

5. Yamazaki T, McLoughlin GS, Patel S, Rhines LD, Fourney DR. Feasibility and safety of en bloc resection for primary spine tumors: a systematic review by the Spine Oncology Study Group. Spine (Phila Pa). 2009; 34(22 Suppl.):S31-38.

6. Clarke MJ, Mendel E, Vrionis FD. Primary spine tumors: diagnosis and treatment. Cancer Control. 2014; 21(2):114-23.

7. Murphy MD, Andrews CL, Flemming DJ, Temple HT, Smith WS, Smirnotopolous JG. Primary tumors of the spine: radiologic pathologic correlation. Radiographics. 1996; 16(5):1131-58.

8. McAllister VL, Kendall BE, Bull JW. Symptomatic vertebral haemangiomas. Brain. 1975; 98(1):71-80.

9. Slon V, Stein D, Cohen H, Sella-Tunis T, May H, Hershkovitz I. Vertebral hemangiomas: their demographical characteristics, location along the spine and position within the vertebral body. Eur Spine J. 2015; 24(10):2189-95.

10. Schrock WB, Wetzel RJ, Tanner SC, Khan MA. Aggressive hemangioma of the thoracic spine. J Radiol Case Rep. 2011; 5(10):7-13.

11. Goldstein CL, Varga PP, Gokaslan ZL, Boriani S, Luzzati A, Rhines L, et al. Spinal hemangiomas: results of surgical management for local recurrence and mortality in a multicenter study. Spine (Phila Pa). 2015; 40(9):656-64.

12. Issa $M$, Lucas $G$, Violas $P$, Griffet J, Courvoisier A. Vertebroplasty for vertebral hemangioma in children: a report of two cases with 2-year follow-up. Childs Nerv Syst. 2015; 31(11):2179-83
13. Amacher AL, Eltomey A. Spinal osteoblastoma in children and adolescents. Childs Nerv Syst. 1985; 1(1):29-32.

14. Acosta FL Jr, Sanai N, Chi JH, Dowd CF, Chin C, Tihan T, et al. Comprehensive management of symptomatic and aggressive vertebral hemangiomas. Neurosurg Clin North Am. 2008; 19(1):17-29.

15. Jackson RP, Reckling FW, Mantz FA. Osteoid osteoma and osteoblastoma: similar histologic lesions with different natural histories. Clin Orthop. 1977; 128:303-13.

16. Janin Y, Epstein JA, Carras R. Osteoid osteoma and osteoblastomas of the spine. Neurosurgery. 1981; 8(1):31-42.

17. Kaweblum M, Lehman WB, Bash J, Grant AD, Strongwater A. Diagnosis of osteoid osteoma in the child. Orthop Rev. 1993; 22(12):1305-11.

18. MacLellan DI, Wilson FC. Osteoid osteoma of the spine: a review of the literature and report of six new cases. J Bone Joint Surg Am. 1967; 49(1):111-6.

19. Cohen MD, Harrington TM, Ginsburg WW. Osteoid osteoma: 95 cases and a review of the literature. Semin Arthritis Rheum. 1983; 12(3):265-81.

20. Uehara M, Takahashi J, Kuraishi S, Shimizu M, Ikegami S, Futatsugi T, et al. Osteoid osteoma presenting as thoracic scoliosis. Spine J. 2015; 15(12):e77-81.

21. Yalcinkaya U, Doganavsargil B, Sezak M, Kececi B, Argin M, Basdemir G, et al. Clinical and morphological characteristics of osteoid osteoma and osteoblastoma: a retrospective single-center analysis of 204 patients. Ann Diagn Pathol. 2014; 18(6):319-25.

22. Cappuccio M, De Iure F, Amendola L, Corghi A, Gasbarrini A. Cervical osteoid osteoma progression to osteoblastoma. Spine J. 2014; 14(6):1070-1.

23. Shaikh MI, Saifuddin A, Pringle J, Natali C, Sherazi Z. Spinal osteoblastoma: CT and MR imaging with pathological correlation. Skeletal Radiol. 1999; 28(1):33-40.

24. Hakim DN, Pelly T, Kulendran M, Caris JA. Benign tumours of the bone: a review. J Bone Oncol. 2015; 4(2):37-41.

25. Joaquim AF, Giacomini L, Ghizoni E, Tedeschi H. Aneurysmatic bone cyst of the craniocervical region: surgical technique. J Neurosci Rural Pract. 2014; 5(1):55-8.

26. Erol B, Topkar MO, Caliskan E, Erbolukbas R. Surgical treatment of active or aggressive aneurysmal bone cysts in children. J Pediatr Orthop B. 2015; 24(5):461-8.

27. Flont P, Kolacinska-Flont M, Niedzielski K. A comparison of cyst wall curettage and en bloc excision in the treatment of aneurysmal bone cysts. World J Surg Oncol. 2013; 11:109-17.

28. Harrop J, Schmidt M, Boriani S, Shaffrey CI. Aggressive "benign” primary spine neoplasms: osteoblastoma, aneurysmal bone cyst, and giant cell tumor. Spine (Phila Pa). 2009; 34(22 Suppl):S39-47.

29. Broadbent V, Egler RM, Nesbit ME Jr. Langerhans cell histiocytosis - clinical and epidemiological aspects. Br J Cancer Suppl. 1994; 23:S11-24.

30. Velez-Yanguas MC, Warrier RP. Langerhan cell histiocytosis. Orthop Clin North Am. 1996; 27(3):615-34.

31. Lam S, Reddy GD, Mayer R, Lin Y, Jea A. Eosinophilic granuloma/Langerhans cell histiocytosis: pediatric neurosurgery update. Surg Neurol Int. 2015; 6(Suppl 17):S435-9.

32. Montalti M, Amendola L. Solitary eosinophilic granuloma of the adult lumbar spine. Eur Spine J. 2012; 21(Suppl 4):441-4.

33. Prichtard DJ, Dahlin DC, Dauphine RT. Ewing's sarcoma: a clinic pathologic analysis of patients surviving 5 years or longer. J Bone Joint Surg. 1975; 57:10-6.

34. Toni A, Neff JR, Sudanese A, Ciaroni D, Bacci G, Picci P, et al. The role of surgical therapy in patient with nonmetastatic Ewing's sarcoma of the limbs. Clin Orthop. 1993; 286:225-40.

35. Grubb MR, Currier BL, Pritchard DJ, Ebersold MJ. Primary Ewing's sarcoma of the spine. Spine (Phila Pa). 1994; 19(3):309-13.

36. Sharafuddin MJ, Haddad FS, Hitchon PW, Haddad SF, el-Khoury GY. Treatment options in primary Ewing's sarcoma of the spine: report of seven cases and review of the literature. Neurosurgery. 1992; 30(4):610-8.

37. Katonis P, Datsis G, Karantanas A, Kampouroglou A, Lianoudakis S, Licoudis S, et al. Clin Med Insights Oncol. 2013; 7:199-208.

38. Tasdemiroglu E, Bagatur E, Ayan I, Darendeliler E, Patchell RA. Primary spinal column sarcomas. Acta Neurochir (Wien). 1996; 138(11):1261-6.

39. Joaquim AF, Powers A, Laufer I, Bilsky MH. An update in the management of spinal metastases. Arq Neuropsiquiatr. 2015; 73(9):795-802.

40. Klein SL, Sanford RA, Muhlbauer MS. Pediatric spinal epidural metastases. J Neurosurg. 1991; 74(1):70-5.

41. Ray GL, Buchsbaum JC, McMullen KP, Simoneaux RV, Hines M, Douglas JG, et al. Definitive treatment of leptomeningeal spinal metastases in children. Pediatr Blood Cancer. 2013; 60(11):1839-41.

42. Joaquim AF, Cheng I, Patel AA. Postoperative spinal deformity after treatment of intracanal spine lesions. Spine J. 2012; 12(11):1067-74. 